JELTL (Journal of English Language Teaching and Linguistics) e-ISSN: 2502-6062, p-ISSN: 2503-1848

2018, Vol. 3(3)

www.jeltl.org

\title{
Theoretical Framework of Stance: An Introduction of A New Analytical Category, Neutral Epistemic Stance
}

\author{
Sani Yantandu Uba \\ Dhofar University, Oman \\ e-mail:suba@du.edu.om \\ Mike Baynham \\ University of Leeds. United Kingdom \\ e-mail: M.Baynham@education.leeds.ac.uk
}

\begin{abstract}
This paper extends Hyland's (2005) theoretical framework of stance through the introduction of an additional analytic category of stance, neutral epistemic stance corresponding to Mushin's (2001) factual epistemological stance. This article reviews various theoretical frameworks of stance and argues that none of these theoretical frameworks provide neutral linguistic markers of stance in academic writing. Using a corpus of twelve accounting PhD theses I conducted a textual analysis of different rhetorical sections between the theses, identifying what stance markers are used and why such stance markers are used and in what linguistic context such markers are used. This process led me to identify a new analytical category, neutral epistemic stance. This study contributes to the ongoing literature on stance in academic writing, arguing that unevaluated stance is also indicating taking up a neutral stance and can be understood as part of 'doing objectivity' in academic writing.
\end{abstract}

Keywords: stance, neutral epistemic stance, epistemological stance, factual epistemological stance 


\section{INTRODUCTION}

Stance has emerged in the literature on academic writing in a major way, and as an important and pervasive mechanism by which academic writers 'inhabit' their writing and give it distinctiveness (Baynham, 2011, 2014). Stance is also concerned with 'adopting a point of view in relation to both the issues discussed in the text and to others who hold points of view on those issues' (Hyland, 2005: 175). In this study, the concept of stance is broadly defined as the linguistic mechanisms that writers are employing to express their own points of view in relation to informational content or propositions, as well as in relation to their readers in their academic writing. A number of scholars have explored the theoretical frameworks of stance with different levels and different analytical frameworks. For example, 'evidentiality' (Chafe, 1986), 'affect' (Ochs, 1989), 'evaluation' (Hunston, 1994; Hunston and Thompson, 2000; Bondi and Mauranen, 2003), 'appraisal' (Martin, 2001), 'attitude' (Halliday, 1994), 'metadiscourse' (Crismore, Markkanen, Steffensen, 1993;Crismore, 1989; Hyland and Tse, 2004), 'intensity' (Labov, 1984), and 'stance' (Biber and Finegan, 1988, 1989; Hyland, 1999a; Biber, Johansson , Leech, Conrad and Finegan, 1999; Barton, 1993; and Conrad and Biber, 2000). However, it seems that none of the previous frameworks of stance in academic writing talk about neutral epistemic stance. This study aims to extend Hyland's (2005) theoretical framework of stance through an introduction of a new analytical category of stance, neutral epistemic stance, illustrating the argument with data from a study of stance-taking from accounting PhD theses (Uba, 2017).

\section{LITERATURE REVIEW}

\subsection{Linguistic and social constructionist views of epistemology}

Bazerman (1988: 323) asserts that epistemology 'cannot be separated from its rhetoric'. This suggests that 'our beliefs about the nature of knowledge are formulated, shared, and performed linguistically' (Weston, 2014: 23). Bazerman argues further that rhetoric must be 'appropriate and effective' and in tandem with 'the epistemology and goals of the community in which you are participating', as well as that language must be 'harmonious' which will conform to 'the epistemological commitments of one's audience' (1988: 323-324). Thus, epistemology is variable, and that language use is variable on the basis that if you want to 'make your claims intelligible and persuasive', then there is a need to express your claims in a way that will match the epistemology of your particular discourse community (Bazerman, 1988: 324).

Bazerman's argument suggests a relationship between linguistic form and epistemological commitment. He also states that 'claims can be linguistically reformulated so as to evoke different epistemological commitments' (Weston, 2014: 24). For Baynham (2014: 68) a linguistic of identity can be 'situated in relation to what we now know about language and subjectivity'. I now turn my attention to a related concept, epistemological stance. 


\subsection{Epistemological stance}

Mushin (2001: 52) claims that 'the relationship between speakers and their knowledge of what they talk about is more complex than simply mapping sources of information onto language forms'. Echoing the position taken by Bazerman, he suggests that speakers/writers may not only pay 'attention to how they have come to know what they know, they must also assess the context in which they have chosen, or are required to, talk about such topics' (Mushin 2001: 52). She posits that when people are verbally representing a piece of knowledge, speakers/writers take up a necessary stance on how they acquired the information, and how they know it. For example, a speaker may say 'this is true I saw it with my own eye' or 'this is true I was told about it by someone reliable'. This relates to the concept of evidentiality which refers to how writers express their commitment to the reliability of the informational content they present, as well as their potential impact on the readers (Hyland, 1999a; 2005b). Mushin (2001) also notes that this is the speaker, writer's epistemological stance towards the information (pp: 52). She also states that the concept of epistemological stance 'is a necessary part of the construal of information, operating in conjunction with other necessary parts', such as an understanding of spatio-temporal coordinates and the relationship between the speaker and addressee(s), etc. (pp: 52). This in essence implies that speakers/writers take up a stance towards the information they have acquired by taking into account of the spatio-temporal, the relationship between the speaker and the addressees, as well as the disciplinary discourse. Mushin (2001) states further that:

Epistemological stance is about both the underlying pragmatic pressures that motivate the conceptualisation of information in terms of a speaker's assessment of her knowledge, and the internal structure of these conceptualisation that result in a variety of mappings onto linguistic structure (pp: 52).

This indicates that epistemological stance operates at two levels: pragmatic pressure which motivates conceptualisation of information in terms of speakers' assessment of knowledge and the internal structure which emphasises mappings onto linguistic structure. For example, at conceptual structure level, epistemological stance is independent of linguistic form, which it can be expressed by 'any of grammatical, lexical or paraphrastic means'; however, the 'motivation that speakers have to adopt a particular epistemological stance is a pragmatic issue' (Mushin, 2001: 53). This can only be 'addressed through an analysis of speakers' linguistic strategies used to represent the status of knowledge' (Mushin, 2001: 53).

Mushin (2001: 58) states further that speakers are motivated to take up a particular epistemological stance 'partially on the basis of their source of information, but also on the basis of their rhetorical intentions', but also of course, in relation to the issue of academic writing to distinctive epistemological traditions of the discipline they are writing in. She also claims that if speakers come across with multiple sources of information they may weigh up the overall status of the information; and may choose one type of source based on the stance they take. Such choice is 'dependent on their overall communicative goals' (pp: 58). 
She claims further that speakers may take up a range of epistemological stances on particular issues dependent 'on the conceptualising individual's assessment of how they acquired their information based on cultural conventions and interactive goals' (pp: 59). This view is consonant with Bazerman that speakers/writers must ongoinly select an 'appropriate and effective' epistemological stance towards the informational content and the disciplinary community. This foregrounds a wide range of epistemological stances that are available to speakers/writers to select 'appropriate and effective' epistemological stance which will conform to the rhetoric and conventions of the disciplinary discourse.

Chafe and Nichols (1986) who also write about evidentiality view epistemic stance as knowledge or belief vis-à-vis some focus of concern, including degree of commitment to truth of propositions, degree of certainty of knowledge and sources of knowledge, among other epistemic qualities. Gray and Biber (2012:15) review the conception of epistemological stance in linguistic studies; and their study suggests that 'the expression of stance varies along two major parameters:

a. Meaning of the assessment: personal feeling/attitude, status of knowledge

b. Linguistic level used for assessment: lexical, grammatical

In the first parameter, Gray and Biber have claimed that stance may convey both epistemic and affective information. In the second parameter, epistemic stance can be viewed or interpreted at one level as involving explicit linguistic expression. The epistemological stance has different types; I now briefly discuss only one type which is of relevance to this study.

\subsubsection{Factual epistemological stance}

Factual epistemological stance is concerned with the dissociation of the speaker/writer 'herself from the representation, resulting in a maximally objective construal' (Mushin, 2001: 75). This means that factual epistemological stance is particularly concerned with the objectivity of the informational content presented in a discourse and the speaker/writer distances himself/herself from the information. The thesis of this argument is to do with speakers/writers taking up what I termed 'unevaluated' stance towards the propositions or informational content presented in their discourse. Mushin's framework is not purely on academic or written discourse rather is centrally on spoken discourse. In this paper I consider its implications for stance-taking in academic writing.

Having discussed the concept of epistemological stance, I now turn my attention to review some of the theoretical frameworks of stance, including Hyland's theoretical framework.

\subsection{Critical review of theoretical framework of stance}

As noted above, the concept of stance has been investigated by many scholars. The work of Biber and Finegan (1988) is one of the earliest studies on stance. They investigate the variations of stance in spoken and written registers. They view stance as linguistic features which express speakers' or writers' attitude towards their proposition (Biber and Finegan, 1988: 2). The attitudinal markers can express certainty, feelings, judgements, as well as expressing the degree of truthfulness to 
the reliability of the information. In their classification of stance markers, they exclusively consider only grammatical devices, which are specifically concerned with adverbials; and exclude any lexical features which are expressing attitudes. They categorise stance into six different semantic groups: conviction/certainty, actuality, manner of speaking, approximation, attitudes and possibility/likelihood. One of the limitations of this framework is that they limit their category on adverbials only that their classification is more to do with grammatical devices and downplays lexical features which express attitudes.

Biber, Johansson, Leech, Conrad and Finegan (1999) extend the previous framework of Biber and Finegan (1988), by including stance markers which convey semantic distinction. They categorise stance markers into three broad categories: attitudinal, which expresses 'the speaker's attitude or evaluation of the content' (ibid: 764); epistemological stance, which is concerned with the certainty, limitations, and reliability of the informational content, including the source of the information; and style of stance, which Biber and Conrad (2000) claim that it 'describes the manner in which the information is being presented' (p: 57).

Crismore, Markkanen, and Steffensen (1993) examine metadiscourse across two cultural contexts in the university text without looking at disciplinary discourse. They classify metadiscourse into two groups: textual metadiscourse and interpersonal metadiscourse. My own concern in this study is an interpersonal metadiscourse, which emphasises how academic writers engage in an interpersonal interaction with informational content and their readers in academic texts. Their list of interpersonal metadiscourse does not incorporate a neutral stance marker category. Martin (2000) uses the concept of 'appraisal' which he categorises it into three groups: affect, deals with expressing emotional responses (happiness and sadness); judgment is used for construing moral evaluations of behaviour (ethical, deceptive, etc,); and appreciation, deals with aesthetic assessment (subtlety, beauty, etc). He links these three concepts to engagement which he refers to dealing with the 'speakers' degree of commitment to the appraisal being expressed' (p.143). For example, he categorises 'affect' into 'irrealis affect' and 'realis affect'. Hunston (2000) examines evaluative linguistic features across genres: RAs, political and social comment articles from The Times and The Guardian newspapers and book reviews. Her study is not purely on academic written genres rather she combines analysis of this with newspaper genre. Although she provides many examples of evaluative words in its linguistic context unlike the previous frameworks, such as:

Some have claimed that they were... (p: 191)

Unfortunately some track should be kept of religious... (p: 192)

Biber (2006) extends the previous frameworks of Biber et al. (1999) and Biber and Conrad (2000). In this framework he compares linguistic markers of stance between university academic and management registers. Unlike previous frameworks, in this framework he includes modals, semi-modals, adverbs, as well as stance complement clauses. This framework is more to do with the lexico-grammar in spoken and written university registers. Though Biber extends the previous frameworks, some of the stance markers he categorises under different grammatical 
categories have same meanings. For example, adjectives of certainty 'clear, obvious, certain; verbs, know, believe; adverbs, certainly, in fact; and noun fact, all these could converge on same meaning or function in a specific context. Yet, he categorises them under different grammatical categories. He pays more attention to form rather than meaning.

Bednarek (2006) also develops a theoretical framework of evaluation from the perspective of media discourse. Her framework includes evidentiality and modality. She extends the previous frameworks of evaluation by combining and modifying them. In this framework, she includes more variables, which previous frameworks exclude. For example, she incorporates evaluations of discourse, actions, processes and entities; whereas previous frameworks are more concerned with evaluation of propositions and attitude markers, which express personal feelings (Bednarek 2006). This new framework has two categories of evaluations: Core Evaluative Parameters and Peripheral Evaluative Parameters. The former is concerned with 'evaluative qualities ascribed to the entities, situations or proposition that are evaluated, and involve evaluative scales with two opposite poles, but (have) potential intermediate stages between them' (Bednarek 2006: 44). It has six subcategories: reliability, possibility/necessity, emotivity, expectedness, comprehensibility and importance. On the other hand, Peripheral Evaluative Parameters is concerned with assessing the style of knowledge, the evidence of knowledge, as well as social actors. They have three categories of values: evidentiality, mental-state and style.

As discussed above Bednarek (2006) claims that the core evaluative values deal with evaluating world entities; whereas the peripheral values are concerned with authors' taking up a stance. However, she does not take into account that when someone is evaluating world entities he/she is implicitly or explicitly taking up a stance towards such entities.

I now turn my attention to Hyland's model of linguistic markers of stance and argue that the strength of the model is that it incorporates various aspects of stance into one concept and provides a wide range of linguistic markers of stance, which none of the previous frameworks incorporate. However, I also argue that the model has certain limitations which need to be evaluated. I argue for that the extension of this framework to include what I will term neutral epistemic stance, corresponding to Mushin's notion of factual epistemological stance discussed above

\subsection{Hyland's linguistic markers of stance}

As noted above, due to the importance of stance in academic writing, many scholars have explored the concept from different perspectives. However, there are some limitations of certain theoretical frameworks of linguistic markers of stance being explored by many scholars. For example, none of the previous frameworks incorporate the notion of explicit presence of the author in a text through the use of explicit self-mention features (Biber and Finegan, 1988, 1989; Biber, et al. 1999; Barton, 1993; and Conrad and Biber, 2000). Furthermore, some deal with broader concept of evaluation, such as Bednarek (2006) and Hunston (2000), while others look at one aspect of stance, such as 'hedging' (Holmes, 1988). Moreover, some frameworks as noted above are concerned with whole aspect of metadiscourse such 
as (Crismore et al. 1993); whereas my study is only concerned with interactional aspect of metadiscourse that of stance.

Following this, it seems there is at times a lack of clear definitional boundaries of linguistic categories of the concept of stance and different terms have been used by different scholars. Unlike previous frameworks Hyland's (2005a) framework makes an attempt to be comprehensive: to incorporate all those parts of stance (evidentiality, affect, and explicit presence of the author) into one- stance framework. His framework covers extensively on the academic writing drawing on different aspects of evidentiality. He pulls together the features of diverse approaches into a single coherent framework.

The concept of stance from the perspective of Hyland has three main components: evidentiality, affect, as well as presence. I will now briefly discuss each one of them.

a. Evidentiality refers to how writers express their commitment to the reliability of the informational content he/she presents, as well as their potential impact on the readers (Hyland, 1999a; 2005b). This assessment of possibility and the degree of confidence of what has been said range from categorical assurance to uncertain potentiality (Coates, 1983; Palmer, 1990; and Hyland, 1999a, 2005b, 2012a). This suggests that writers may either take up a range of stances from categorical assurance to uncertainty on propositions. Moreover, these epistemic uses of language perform significant interactional functions which indicate group membership (Hyland, 1999). Epistemic comment is one of the major features that writers use flexibly to take up stances, signal allegiances, and express points of view (Biber, 2006; Hyland, 1999a, 2005b; Lyons, 1977; and Stubbs, 1996).

b. Affect is concerned with how writers express their professional and personal attitudes towards what has been said, including emotions, perspectives and beliefs (Hyland, 2005b). Hyland argues further that language can never be ideological neutral because it serves to express and organise experience and always codes perspective and orientation.

c. Presence refers to the extent to which writers present or make themselves present in the complex text (Hyland, 1999, 2005b). It is also concerned with how writers present themselves and their audiences in a complex text in order to contribute the level of detachment and engagement (Hyland, 1999, 2005b; Hyland and Guinda 2012). Hyland's framework has four basic analytical categories of stance: booster, hedge, attitude marker and explicit self-mention features (Hyland, 2005).

Despite extensive coverage of the concept, as well as providing a wide range of stance markers from this model, which none of the previous frameworks do. In this paper I argue that the framework does not talk about the notion of neutral epistemic stance, which is concerned, as I suggest above, with the writers' taking up a neutral stance towards the proposition or informational content. The 'neutral' epistemic stance, corresponding to Mushin's notion of factual epistemological stance, does the work of 'objectivity' in the sense that one of the things that academic writers needs to do is to report phenomena as fact. In this instance 'the reporting of plain bare facts' does the work of objectivity because the author takes 
up a neutral stance which is also part of objectivity in academic writing. For example,

This is observed by DeYong and Hasan (1998) and Shaffer (1998) in their studies when they state that it takes on average about six years (Doc 6:9).

Poyi (2006) mentions that the CBN'S ratings of all the banks as at the end of March 2004 classified 62 as sound /satisfactory, 14 as marginal ... (Doc 6: 4)

In these types of instances, the writers report plain facts without taking up any absolute or partial commitment to the propositions or informational content but rather pass the information as plain facts; as such they take up a neutral stance towards the propositions or informational content, which is also doing the work of rhetorically constructing objectivity. As noted above, Hyland's framework and indeed previous frameworks which I have found less comprehensive than Hyland's, do not incorporate the concept of neutral epistemic stance.

In the light of the above weakness of Hyland's framework and other previous frameworks mentioned above of none of them incorporate neutral stance, this study aims to extend Hyland's framework of stance by arguing that there should be an additional analytical category of stance, neutral epistemic stance, corresponding to Mushin's Factual epistemological stance. This study seeks to address the following question:

1. What linguistic markers of stance typically express taking up a neutral stance in academic writing?

\section{RESEARCH METHODS}

\subsection{Criteria for the corpus selection}

In order to address the above research question, I looked at twelve accounting $\mathrm{PhD}$ theses in both British and Nigerian universities. I set up the following criteria for the selection of the theses:

a. all accounting $\mathrm{PhD}$ theses must have been written and successfully passed their $\mathrm{PhDs}$ in the period from 2007 to 2015.

b. although many scholars have identified four different types of thesis in terms of its macro-structure (Paltridge, 2002), including simple traditional (introduction, review of literature, methods, results, discussion, and conclusion), complex traditional, topic-based, and anthology. I have selected only theses which have identifiable macro-structures of introduction, review of literature, methods, results, discussions, and conclusions sections. I have chosen this because in the disciplines of Humanities and Social Sciences have typically been using the simple traditional type of thesis.

\subsection{Procedures for identifying a new analytical category of neutral stance marker}

As noted above some of the limitations of the Hyland's typology of linguistic markers of stance and other previous frameworks. I now present procedures which I 
followed in identifying a new category of stance marker, neutral stance marker. I followed a two-step procedure in identifying this new analytical category.

\subsubsection{Step One: Looking at different rhetorical sections between the accounting PhD theses}

As discussed above, this paper aims to introduce an additional analytical category of stance. I first looked at different rhetorical sections of the twelve accounting $\mathrm{PhD}$ theses to identify what stance markers are used; why such stance markers are used and in what linguistic context such markers are used. In order to sample stance markers from the theses I looked at different rhetorical sections, in all covering the whole macrostructures of the $\mathrm{PhD}$ thesis that the accounting $\mathrm{PhD}$ authors used in their theses. In this step, I picked up a hard copy of each thesis, read and reread each rhetorical section looking through the context and cotext of each stance feature identified to verify whether in such context can be considered as a neutral stance marker.

\subsubsection{Step two: identifying my own list of neutral stance markers}

I noted above the procedure for identifying and verifying each linguistic marker in its linguistic context. I finally came up with my own complete list of neutral stance markers (see complete list of my own stance markers in table 1 below).

\section{RESULTS}

I highlighted some of the limitations of the previous theoretical frameworks of stance, including non-inclusion of neural stance markers. I have also stated that I will extend previous theoretical frameworks of stance through the introduction of an additional analytical category which I termed neutral stance markers influenced by Mushin's factual epistemological stance. I now present neutral stance markers identified in the study. The results of textual analysis shows that there are neutral stance markers that author typically uses to report plain facts without taking up any absolute or partial commitment to the informational content or proposition but rather passes the information as plain facts, as such he/she takes up a neutral stance towards the propositions or informational content, thus doing the work of objectivity. For example, some $\mathrm{PhD}$ authors say:

Jonas and Blanchet (2000) described the two general perspectives widely used in assessing the quality of financial reports as meaningful (Doc 5: 8)

He states that, external auditors must be educated, well trained and experienced professional accountant... (Doc 4: 20)

Poyi (2006) mentions that the CBN'S ratings of all the banks as at the end of March 2004 classified 62 as sound /satisfactory, 14 as marginal ... (Doc 6: 4)

Bailey et al. (2003) note that unlike in the past when external audit function is looked upon for solution to corporate scandals, now many are looking to the IAF as part of the solution to the 
perceived control, reporting and ethical problems in the private sector (Doc 4:21L)

While authors like Elmuti and Kathawala (2000) and Momme (2001) view outsourcing as the strategic use of specialised and efficient outside providers... (Doc 4: 26)

These instances indicate that the writers do not take any absolute or partial stance towards the authors' propositions or information but they present the plain facts of the authors. Thus, the propositions are considered unevaluated statement. I will now present the complete list of stance markers which I consider to function as a neutral epistemic stance.

Table 1: A complete list of neutral stance markers identified in the accounting $\mathrm{PhD}$ theses

\begin{tabular}{|l|l|}
\hline $\begin{array}{l}\text { Serial } \\
\text { Number }\end{array}$ & Neutral stance marker \\
\hline 1 & View \\
\hline 2 & Opine \\
\hline 3 & State \\
\hline 4 & Mention \\
\hline 5 & See \\
\hline 6 & Describe \\
\hline 7 & Argue \\
\hline 8 & Maintain \\
\hline 9 & Contend \\
\hline 10 & Note \\
\hline
\end{tabular}

Mushin predicts from her work there should be a category of unevaluated stance and my review of stance frameworks shows that none of them include this. However, this empirical study shows that there is. Therefore, I propose extending Hyland's framework to include this category.

\section{CONCLUSION}

This study contributes to the ongoing literature on the use of stance markers in academic writing, as noted above, it extends Hyland's framework by proposing the inclusion of an additional analytic category, influenced by Mushin's factual epistemological stance.

One limitation of this study is the size of the corpus. It is not a large corpus as can be seen above it involves $12 \mathrm{PhD}$ theses across two different regions. The corpus comprises only discipline of accounting, as well as one academic genre, $\mathrm{PhD}$. This study recommends a further study, involving an expanded corpus comprising different academic genres across many disciplines. This could bring more insights on the use of neutral stance markers in academic texts. 


\title{
6. CONFLICT OF INTEREST
}

There is no conflict of interest in this research.

\begin{abstract}
About the author
Dr. Sani Yantandu Uba has been teaching English language in a university. His research interests are Corpus Linguistics, English for Academic and Special Purposes, Discourse Analysis, Second Language Acquisition etc. He publishes many articles in those areas.
\end{abstract}

\section{REFERENCES:}

Baynham, M. (2011). Stance, positioning, and alignment in narratives of professional experience. Language in Society. 40(01), pp.63-74.

Baynham, M. (2014). Identity: Brought about or brought along: Narrative as a privilege site for researching interculturla identities. London: Routledge.

Bazerman, C. (1988). Shaping written knowledge. Madison: University of Wisconsin Press

Bednarek, M. (2006). Evaluation in media discourse: Analysis of a newspaper corpus. London: Continuum

Biber, D. (2006). Stance in spoken and written university registers. Journal of English for Academic Purposes. 5(2), pp.97-116.

Biber, D. and Finegan, E. (1988). Adverbial stance types in English. Discourse Processes. 11(1), pp.1-34.

Biber, D. and Finegan, E. (1989). Styles of stance: lexical and grammatical marking of evidentiality and affect. Text. 9(1), pp.93-124.

Biber, D., Johansson, G, Leech, G., Conrad, S. and Finegan, E. (1999). The Longman

Chafe, W.L. (1986). Evidentiality in English conversation and academic writing. Norwood, NJ: Ablex

Conrad, S. and Biber, D. (2000). Adverbial marking of stance in speech and writing. Oxford.: Oxford University Press

Crismore, A. (1989). Talking with readers: metadiscourse as rhetorical act. New York: Peter Lang

Crismore, A., Markkanen, R. and Steffensen, M. S. (1993). Metadiscourse in persuasive writing a study of texts written by American and Finnish university students. Written Communication. 10(1), pp.39-71.

Du Bois, J. W. (2007). The stance triangle. In R. Englebretson (ed), Stancetaking in discourse: Subjectivity, evaluation, interaction, Amsterdam: John Benjamins, pp.139-182.

Gray, B. and Biber, D. (2012). Current conceptions of stance. In K. Hyland and C.S. Guinda (eds), Stance and Voice in Written Academic Genres. Hampshire: Palgrave pp.15-33

Halliday, M.A.K. (1994). An introduction to functional grammar. London: Arnold 
Holmes, J. (1988). Doubt and certainty in ESL textbooks. Applied Linguistics. 9(1), pp.21-44.

Hunston, S. 1994. Evaluation and organization in a sample of written discourse. London: Routledge.

Hunston, S. and Thompson, G. (2000). Evaluation in text: authorial stance and the construction of discourse. New York, USA: Oxford University Press.

Hyland, K. (1999a). Disciplinary discourses: Writer stance in research articles. London: Longman

Hyland, K. (2005a). Metadiscourse. London: Continuum.

Hyland, K. (2005b). Stance and engagement: A model of interaction in academic discourse. Discourse Studies. 7(2), pp.173-192.

Hyland, K. and Tse, P. (2004). Metadiscourse in academic writing: a reappraisal. Applied Linguistics. 25(2), pp.156-177

Labov, W. (1984). Intensity. Washington, DC: Georgetown University Press.

Lyons, J. (1977). Semantics (vols I \& II). Cambridge: Cambridge University Press.

Martin, J. R. (2001). Language, register and genre. London: Routledge.

Mushin, I. (2001). Evidentiality and epistemological stance: Narrative retelling. Amsterdam: John Benjamins Publishing

Ochs, E. (1989). The pragmatics of affect. Berlin: Mouton de Gruyter

Paltridge, B. (2002). Thesis and dissertation writing: an examination of published advice and actual practice. English for Specific Purposes. 21(2), pp.125-143.

Stubbs, M. (1996). Text and corpus analysis. London: Blackwell

Weston, J. (2014). The Linguistic Construction of Epistemological Difference. Unpublished PhD thesis: University of London: London, UK

Uba, S. Y. (2017). Authorial stance in accounting PhD theses in a Nigerian university. Unpublished PhD thesis: University of Leeds: Leeds, UK 